\title{
One-pot catalytic conversion of cellulose to ethylene glycol and other chemicals: From fundamental discovery to potential commercialization
}

\author{
Mingyuan Zheng, Jifeng Pang, Aiqin Wang, Tao Zhang* \\ State Key Laboratory of Catalysis, Dalian Institute of Chemical Physics, Chinese Academy of Sciences, Dalian 116023, Liaoning, China
}

\section{A R T I C L E I N F O}

Article history:

Received 21 November 2013

Accepted 30 December 2013

Published 20 May 2014

\section{Keywords:}

Biomass

Cellulose

Ethylene glycol

Tungstenic catalyst

Hydrogenation

\begin{abstract}
A B S T R A C T
The one-pot catalytic conversion of cellulose to ethylene glycol (CEG) is a highly attractive way for biomass utilization to lessen the consumption of fossil energy resources. In this paper, we reviewed the disclosure of the CEG process and the rapid progress in the development of highly efficient and robust catalysts for it. Based on our study of tungstenic catalysts, we discuss the reaction mechanism, in which the reaction routes, catalyst states, and catalytic roles of the tungsten species and hydrogenation sites in the cascade reactions are understood clearly. With future applications in mind, the conversion of raw cellulosic biomass and the strategy to develop an efficient CEG process for commercialization are discussed, and a model where the CEG process is incorporated into a bio-refinery process of acetone- $n$-butanol-ethanol (ABE) production is presented.
\end{abstract}

(C) 2014, Dalian Institute of Chemical Physics, Chinese Academy of Sciences.

Published by Elsevier B.V. All rights reserved.

\section{Introduction}

The growth of the world economy is currently heavily dependent on fossil energy, which has led to grave resource depletion and global environment deterioration. Faced with the great challenges of sustainable development, people are starting to turn towards a variety of clean and renewable energy resources, including hydraulic energy, wind energy, solar energy, and biomass energy to explore new technologies for improving the present situation [1-4].

Cellulose, a nature polymer of carbohydrates, is the most abundant biomass with a huge global production of up to 70 billion ton/year [5]. It stores solar energy and is composed of $\mathrm{C}$, $\mathrm{H}$, and $\mathrm{O}$ atoms, which are the fundamental elements of daily chemicals. Furthermore, cellulose is inedible and exists widely in the residues of agriculture and forestry. Therefore, its utili- zation will not impose a negative effect on food supply nor occupy farming lands. In the past decade, a vast effort has been devoted to the catalytic conversion of cellulosic biomass to fuels and chemicals, which formed a research revival after the first study peak in the 1980s [6-30]. As summarized in many comprehensive reviews, the conversions involve the production of 5-hydroxymethyfurfural and its derivates [16], levulinic acid [25], gamma-valerolactone [26,30], polyols [18,21,23,24], lactic acid [12,28,29], phenols [13,22], etc.

Ethylene glycol (EG) is the largest bulk polyol with a global consumption of up to 21 million ton/year. It is widely used in the synthesis of polyester, antifreeze, etc., and is estimated to have an increasing demand in the coming decades [31]. Currently, EG is mainly produced from petroleum ethylene by selective catalytic oxidation and hydration processes. Some recent endeavors have also been made for the catalytic prepara-

\footnotetext{
* Corresponding author. Tel: +86-411-84379015; Fax: +86-411-84691570; E-mail: taozhang@dicp.ac.cn

This work was supported by the National Basic Research Program of China (973 Program, 2009CB226102) and the National Natural Science Foundation of China (21376239, 21306191, and 21176235).
}

DOI: 10.1016/S1872-2067(14)60013-9 | http://www.sciencedirect.com/science/journal/18722067 | Chin. J. Catal., Vol. 35, No. 5, May 2014 
tion of EG from coal, which is also a fossil carbon resource $[32,33]$. Using cellulose to synthesize EG would notably contribute to alleviating the dependence on fossil energy resources and cut down on $\mathrm{CO}_{2}$ emission. Meanwhile, this process could keep all the atoms from cellulose in the products, and thus it would have a very high atom economy, which is required for green chemistry.

Cellulose is composed of glucan units, which are connected in chains by $\beta$-1,4-glucosidic bonds and form crystalline three dimensional network by inter- and intra-molecular hydrogen bonds. The robust structure of cellulose makes it inert in most solvents and resistant to degradation. The challenges in the catalytic conversion of cellulose to chemicals have three aspects as follows. i) The process should be environmentally benign. The conventional conversion of cellulose by hydrolysis with inorganic acids needs to be replaced by novel green techniques. ii) There is a conflict between the harsh reaction conditions and high reaction selectivity, which needs to be balanced. The stability of cellulose requires harsh reaction conditions for the conversion. However, this is disadvantageous for obtaining target products with high selectivity. iii) The process should be simple. A more complex process has more energy loss and less efficiency in the route of biomass conversion.

In 2006, Fukuoka and coworkers [34] disclosed the one-pot catalytic conversion of cellulose to hexitols. By coupling the hydrolysis of cellulose to glucose and hydrogenation of glucose to stable sorbitol, the process overcame the problem of metastable glucose and obtained a high yield even at relatively high reaction temperatures. After $24 \mathrm{~h}$ reaction at $190{ }^{\circ} \mathrm{C}$ and $5 \mathrm{MPa}$ $\mathrm{H}_{2}$, cellulose was largely degraded into hexitols with a yield of $31 \%$ under hydrothermal conditions. The $\mathrm{Pt} / \mathrm{Al}_{2} \mathrm{O}_{3}$ catalyst can be readily recycled by filtration after the reaction and reused several times. Liu and coworkers [35] further remarkably promoted the efficiency of this process by employing in situ protonic acid in near-critical water. After $30 \mathrm{~min}$ reaction at $245{ }^{\circ} \mathrm{C}$, the hexitol yield was improved to $39.3 \%$ with a $\mathrm{Ru} / \mathrm{C}$ catalyst. The green solvent of water, the heterogeneous catalyst that is readily recycled, and the simple one-pot process are the highlights of the work, which provide inspiration for the catalytic conversion of cellulose to useful polyol chemicals. In the following years, many researchers have extensively investigated the cellulose conversion in one-pot by coupling hydrolysis and hydrogenation to hexitols [36-51]. The catalysts used include Ni/CNF [39], $\mathrm{Ni}_{2} \mathrm{P} / \mathrm{AC}$ [40], Pt/BP2000 [42], $\mathrm{Ru} /$ $\mathrm{Cs}_{3} \mathrm{PW}_{12} \mathrm{O}_{40}$ [44], Ru/AC-SO $3 \mathrm{H}$ [45], 1\%Rh-5\%Ni/MC [46], $\mathrm{Ni} / \mathrm{ZSM}-5$ [50], and solid hydrogenation catalysts in combination with heteropoly acids [38], and give hexitol yield in the range of $31.0 \%-86.1 \%$.

With the target of developing less expensive but more effective and selective catalysts for the one-pot catalytic conversion of cellulose, we commenced the study of tungsten carbide catalysts for the biomass conversion. Under reaction conditions similar to that of Liu et al. [35], to our surprise, we found that over the tungsten carbide catalyst, cellulose was dramatically degraded into EG, which is a $\mathrm{C}_{2}$ small molecule instead of the common products of hexitols that were mainly obtained with noble metal catalysts in the previous works. The highest EG yield reached $61 \%$ on an optimized nickel modified tungsten carbide catalyst in a one-pot catalytic process [52-54]. Because EG is a petroleum-dependent bulk chemical with high value and vast market demand, our new process of the one-pot catalytic conversion of cellulose to EG (CEG) has received extensive attention from both academic and industrial communities $[21,24]$.

After the first report in 2008, more progresses in the study of CEG have been achieved in our laboratory and some other groups in the world [55-66]. Briefly, more effective tungsten carbide catalysts have been obtained by using optimal preparation methods or better supports, which further improved EG yields up to $75 \%[55,67]$. Besides the tungsten carbides, a series of new types of catalysts have been explored. On tungstenic bimetallic catalysts, not only was high EG yield obtained, but also the polyol distribution can be effectively tuned, and the main reaction pathways were disclosed for guiding catalyst design [56]. Composite catalysts of tungstenic acid in combination with a hydrogenation metal catalyst were employed in the CEG process, which integrated homogenous and heterogeneous catalysis in one pot and had very good stability in a long period operation $[59,63]$. With the aim of the practical application of the CEG process, typical raw cellulosic biomass has been employed as the feedstock in the reaction to investigate the effect of pretreatment on the performance of the whole biomass conversion [58,60,61]. All these progress in the past several years have built a good foundation for understanding and utilizing the CEG process and made it a promising green technique for the EG production, which is still dominated by the traditional petrochemical industry to date. In 2013, we reviewed the series of work performed in our group and summarized our fundamental understanding of the reaction mechanism [24].

To more clearly depict the evolving route of the CEG process from fundamental disclosure to future potential application, in this paper, we first reviewed catalyst development for the CEG, including tungstenic catalysts and other types of catalysts. This is followed by a discussion on reaction mechanism understanding for catalyst design and product control. Then, we discuss the progress in the catalytic conversion of raw lignocellulosic feedstock and the strategies to improve reaction efficiency for the purpose of CEG process industrialization. Finally, after giving a model where the CEG process is integrated into a bio-refinery industry for acetone- $n$-butanol-ethanol (ABE) production, we give conclusions and comments on the future development of the CEG process.

\section{Catalyst development for CEG}

Catalysts for the one-pot catalytic conversion of cellulose to EG and chemicals can be classified two categories: (I) tungstenic catalysts and (II) other transition metal based binary catalysts (Table 1). Category I includes tungsten carbides, tungsten phosphides, tungstenic bimetallic catalysts, and tungsten acid based binary catalysts. The common feature in the performance of tungstenic catalysts (category I) is their unique high selectivity to EG, usually approaching 60\%-75\% and much lower yields of other polyols such as 1,2-propylene glycol 
Table 1

Typical catalysts for cellulose conversion to EG and 1,2-PG a .

\begin{tabular}{|c|c|c|c|c|c|c|c|}
\hline Category & Catalyst ${ }^{\mathrm{b}}$ & Reaction conditions & $X / \%$ & $S_{\mathrm{EG}} / \%$ & $S_{1,2-\mathrm{PG}} / \%$ & $S_{\text {Hexitols }} / \%$ & Ref. \\
\hline \multirow[t]{10}{*}{$\mathrm{I}$} & $\mathrm{W}_{2} \mathrm{C} / \mathrm{AC}$ & $518 \mathrm{~K}, 6 \mathrm{MPa} \mathrm{H}, 0.5 \mathrm{~h}$ & 98 & 27.9 & 5.6 & 2.1 & {$[52]$} \\
\hline & $\mathrm{Ni}-\mathrm{W}_{2} \mathrm{C} / \mathrm{AC}$ & $518 \mathrm{~K}, 6 \mathrm{MPa} \mathrm{H} 2,0.5 \mathrm{~h}$ & 100 & 61 & 7.6 & 5.8 & {$[52]$} \\
\hline & $\mathrm{WC}_{\mathrm{x}} / \mathrm{MC}$ & $518 \mathrm{~K}, 6 \mathrm{MPa} \mathrm{H}, 0.5 \mathrm{~h}$ & 100 & 72.9 & 5.1 & 2.6 & {$[55]$} \\
\hline & $\mathrm{Ni}-\mathrm{WC}_{\mathrm{x}} / \mathrm{MC}$ & $518 \mathrm{~K}, 6 \mathrm{MPa} \mathrm{H}$, $0.5 \mathrm{~h}$ & 100 & 74.4 & 4.5 & 5.2 & {$[55]$} \\
\hline & $10 \mathrm{Ni}-\left(30 \mathrm{WC} \mathrm{C}_{\mathrm{x}} / \mathrm{AC}\right)$ & $518 \mathrm{~K}, 6 \mathrm{MPa} \mathrm{H}_{2}, 0.5 \mathrm{~h}$ & 100 & 73.0 & 8.5 & 6.4 & {$[67]$} \\
\hline & $\mathrm{Ni}-\mathrm{WP} / \mathrm{AC}$ & $518 \mathrm{~K}, 6 \mathrm{MPa} \mathrm{H}$, $0.5 \mathrm{~h}$ & 100 & 46.0 & 6.4 & 5.9 & {$[57]$} \\
\hline & $\mathrm{M}(8,9,10)-\mathrm{W} / \mathrm{SBA}-15$ & $518 \mathrm{~K}, 6 \mathrm{MPa} \mathrm{H}_{2}, 0.5 \mathrm{~h}$ & 100 & 76.1 & 3.2 & 8.0 & {$[56]$} \\
\hline & Raney $\mathrm{Ni}-\mathrm{H}_{2} \mathrm{WO}_{4}$ & $518 \mathrm{~K}, 6 \mathrm{MPa} \mathrm{H}$, $0.5 \mathrm{~h}$ & 100 & 65.4 & 3.3 & 10.8 & {$[63]$} \\
\hline & $\mathrm{Ru} / \mathrm{AC}-\mathrm{H}_{2} \mathrm{WO}_{4}$ & $518 \mathrm{~K}, 6 \mathrm{MPa} \mathrm{H}_{2}, 0.5 \mathrm{~h}$ & 100 & 58.5 & 3.5 & 14.0 & [59] \\
\hline & $\mathrm{Ru} / \mathrm{AC}^{-} \mathrm{WO}_{3}$ & $518 \mathrm{~K}, 6 \mathrm{MPa} \mathrm{H}$, $0.5 \mathrm{~h}$ & 100 & 48.9 & 5.4 & 7.6 & {$[62]$} \\
\hline \multirow[t]{6}{*}{ II } & Ru+base buffer & $498 \mathrm{~K}, 6 \mathrm{MPa} \mathrm{H}_{2}, 5 \mathrm{~min}$ & 38 & 15 & 14 & - & {$[68]$} \\
\hline & $\mathrm{Pt}-\mathrm{SnO}_{\mathrm{x}} / \mathrm{Al}_{2} \mathrm{O}_{3}$ & $473 \mathrm{~K}, 6 \mathrm{MPa} \mathrm{H} 2,0.5 \mathrm{~h}$ & 23.8 & 22.0 & 13.5 & 3.9 & [69] \\
\hline & $\mathrm{Ru} / \mathrm{CNTs}$ & $493 \mathrm{~K}, 6 \mathrm{MPa} \mathrm{H}$, $0.5 \mathrm{~h}$ & 81.3 & 21.5 & - & - & {$[70]$} \\
\hline & $\mathrm{Ru} / \mathrm{AC}$ & $433 \mathrm{~K}, 5 \mathrm{MPa} \mathrm{H}, 5 \mathrm{~h}$ & 59.2 & 6.2 & 18.1 & - & {$[71]$} \\
\hline & $\mathrm{Ni} / \mathrm{ZnO}$ & $518 \mathrm{~K}, 6 \mathrm{MPa} \mathrm{H}, 2 \mathrm{~h}$ & 100 & 19.1 & 34.4 & - & {$[72]$} \\
\hline & $\mathrm{Cu}-\mathrm{Cr}-\mathrm{Ca}$ & $518 \mathrm{~K}, 6 \mathrm{MPa} \mathrm{H}, 5 \mathrm{~h}$ & 100 & 31.6 & 42.6 & - & {$[73]$} \\
\hline
\end{tabular}

${ }^{a} X, S_{\mathrm{EG}}, S_{1,2-\mathrm{PG}}$, and $S_{\text {Hexitols }}$ represent cellulose conversion and selectivity for EG, 1,2-PG, and hexitols, respectively.

${ }^{\mathrm{b}} \mathrm{AC}$ and $\mathrm{MC}$ represent active carbon and mesoporous carbon, respectively.

\section{(1,2-PG), sorbitol, and glycerol.}

In contrast, the binary catalysts in category II, Group 8, 9, or 10 metals in combination with basic or amphoteric metal oxides, are less effective and selective to EG formation. They commonly produce more 1,2-PG and glycerol and have lower EG yields in cellulose conversion. Considering that the market capacity for 1,2-PG (1.75 million ton/year) is one twelfth of that of EG, catalysts with high selectivity to EG would be more desirable for cellulose conversion to glycols.

\subsection{Tungsten carbide catalysts}

\subsubsection{First application of tungsten carbide for CEG}

Noble metal catalysts are versatile for a variety of reactions, particularly those involving hydrogen transfer as evidenced by their wide application in the pharmaceutical, agrochemical, and petrochemical industries [74]. In the catalytic transformation of biomass, Pt and Ru catalysts are effective for cellulose conversion to hexitols when the reactions of hydrolysis and hydrogenation are coupled in a one-pot synthesis under hydrothermal conditions. Hexitol yield is $39.3 \%$ with $85.5 \%$ cellulose conversion. However, the scarcity of noble metal resources cannot afford their use for bulk biomass conversion. Moreover, their reaction efficiency and reaction selectivity are still not satisfactory in the initial studies [34,35]. It is highly desirable to develop less expensive but highly effective catalysts for cellulose conversion to polyol chemicals.

Boudart et al. [75] first reported in the 1960s that tungsten carbide catalysts behave like noble metal catalysts in many reactions. The unique catalytic properties of the carbides were attributed to carbon atom insertion into the lattice interstices of the parent metals, which caused a contraction of the $d$ band and led to a $d$ electron density similar to those of noble metals [76-78]. In the past fifteen years, we have extensively investigated the preparation and application of transition metal carbides, nitrides, and phosphides, such as $\mathrm{Mo}_{2} \mathrm{~N}, \mathrm{Mo}_{2} \mathrm{C}, \mathrm{FeN}_{x}, \mathrm{~W}_{2} \mathrm{C}$, and MoP catalysts for the catalytic decomposition of hydrazine [79-89]. We found that tungsten carbide catalysts have excellent activities comparable to those of noble metal Ir catalysts, which have been commercially applied in the catalytic decomposition of hydrazine for spacecraft attitude control. These previous extensive work provided us with a strong background that tungsten carbide catalysts can be promising alternatives to noble metal catalysts for cellulose catalytic conversion.

In 2008, we reported our research results of the one-pot catalytic conversion of cellulose over tungsten catalysts. They were even more efficient than noble metal catalysts with $100 \%$ conversion of cellulose in aqueous solution after $30 \mathrm{~min}$ reaction at $245^{\circ} \mathrm{C}$ and $6 \mathrm{MPa} \mathrm{H}_{2}$. Most intriguingly, the major product was EG but not sorbitol or mannitol, which were mainly obtained with noble metal catalysts as shown in Scheme 1 $[34,35,52,54]$. With the addition of nickel to the tungsten car-

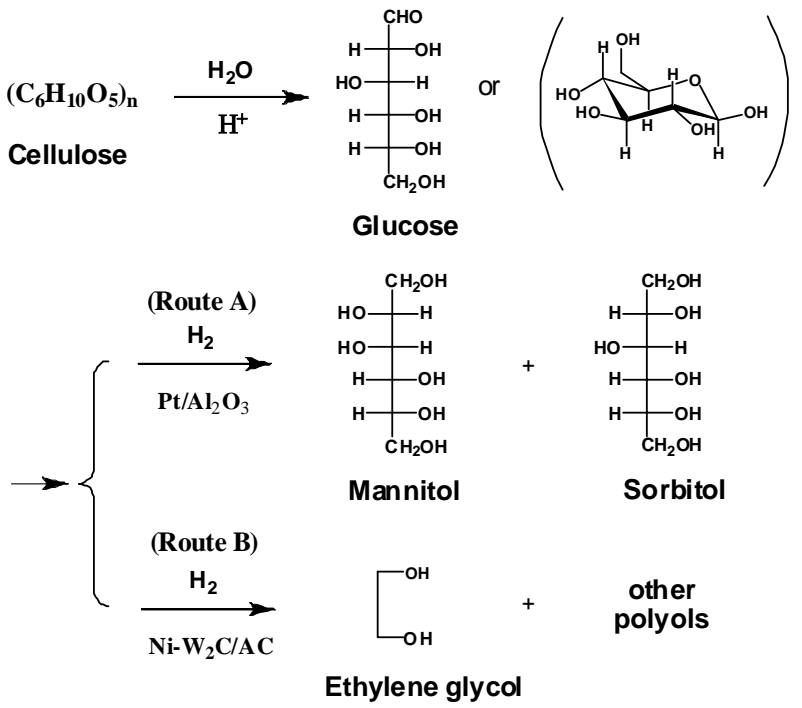

Scheme 1. Catalytic conversion of cellulose over tungsten carbide or $\mathrm{Pt} / \mathrm{Al}_{2} \mathrm{O}_{3}$ catalysts. 
bide, the EG yield was unprecedentedly improved from $27 \%$ to $61.0 \%$ over a $2 \% \mathrm{Ni}-30 \% \mathrm{~W}_{2} \mathrm{C} / \mathrm{AC}$ catalyst. Compared to a variety of biomass conversion routes to chemicals [18] and fuels [14], the one-pot catalytic conversion of cellulose to EG has many very attractive advantages, such as that it is a green reaction process, and has a high value-added product and vast market demand as mentioned above. Therefore, this work provided a novel route for biomass conversion to valuable chemicals.

From the scientific and application points of view, many intriguing questions have arisen since the discovery of the unique performance of tungsten carbide catalysts in cellulose conversion. First, how does the $\mathrm{C}_{2}$ product of EG get selectively produced from the $\mathrm{C}_{6}$ glucose-based polymers? How do the synergistic effects take place between tungsten carbide and metallic nickel to dramatically increase the EG yield? What are the similarities and differences in the catalytic behavior between the tungsten carbide and noble metal catalysts in the catalytic conversion of cellulosic biomass? In the applications in the raw biomass conversion, will the tungsten carbide catalysts be as effective as they are in pure cellulose conversion? In the following years, more work was done to answer these fundamental and practical questions in the CEG process.

\subsubsection{High performance tungsten carbide catalyst}

In the first study of the $\mathrm{Ni}-\mathrm{W}_{2} \mathrm{C} / \mathrm{AC}$ catalyst for cellulose conversion [52], the catalysts were prepared by co-impregnating nickel and tungsten precursors, which decreased the formation temperature of tungsten carbide on the carbon support. However, this method also caused serious sintering of the tungsten carbide particles from the catalytic methanation of the carbon support during the carburization at $700{ }^{\circ} \mathrm{C}$. Two routes were developed to solve the problems. Ji et al. [67] prepared nickel modified tungsten carbide catalysts by a post-impregnation method. It is found that when impregnating nickel precursor solution onto the prepared $\mathrm{W}_{2} \mathrm{C} / \mathrm{AC}$ catalyst, the particles of tungsten carbide were gradually depleted by oxidation under the wet and oxygen atmosphere, by forming soluble tungsten species. The dissolved tungsten species underwent redispersion on the carbon support, followed by co-reduction with nickel to form $\mathrm{W}-\mathrm{Ni}$ alloys at $400{ }^{\circ} \mathrm{C}$ in the subsequent reduction procedure. By utilizing tungsten species redispersion and reduction at low temperatures, the catalyst sintering problem was effectively avoided, which gave highly dispersed tungsten carbide catalysts. Over a $10 \% \mathrm{Ni}-\left(30 \% \mathrm{WC}_{x} / \mathrm{AC}\right)$ catalyst, the $\mathrm{EG}$ yield was improved to as high as $73.0 \%$ in the cellulose conversion.

Another route to obtain high performance catalysts was to employ mesoporous carbon (MC) materials as the support for the tungsten carbide catalyst. Zhang et al. [55] prepared an MC support by a nanocasting method with commercial silica as a hard template and sucrose as a carbon source. The resultant MC has three dimensional connected worm-like mesopores and a high surface area of $1120 \mathrm{~m}^{2} / \mathrm{g}$. With this $30 \% \mathrm{WC}_{x} / \mathrm{MC}$ catalyst, the EG yield approached $72.9 \%$ even without nickel modification of the catalyst, which was notably higher than the $27.4 \%$ and $61.0 \%$ EG yields over the conventional AC-sup- ported catalysts of $30 \% \mathrm{WC}_{2} / \mathrm{AC}$ and $2 \% \mathrm{Ni}-30 \% \mathrm{~W}_{2} \mathrm{C} / \mathrm{AC}$, respectively. The characterization showed that the tungsten carbide dispersion on MC was increased five fold compared to that on the AC-supported catalysts. Some other later studies found that besides acting as a high surface area carrier for the catalysts, the MC itself was capable of activating glucosidic bonds in cellulose and promoting cellulose hydrolysis $[46,90,91]$. These properties as well as the facilitated mass transport of bulky molecules in the mesopores probably accounted for the superior performance of $\mathrm{WC}_{x} / \mathrm{MC}$. In addition, with nickel modification, EG yield was slightly improved to $74.4 \%$ over a $2 \% \mathrm{Ni}$ $\mathrm{WC}_{x} / \mathrm{MC}$ catalyst.

Another remarkable property of the MC supported tungsten carbide catalysts was that they have superior stability compared with those supported on the AC. After four times recycle usage, the EG yield remained at $57.3 \%$ over the $30 \% \mathrm{WC}_{x} / \mathrm{MC}$, which can be largely recovered to $65.9 \%$ once the spent catalyst was regenerated at $550{ }^{\circ} \mathrm{C}$ in a hydrogen atmosphere. The slightly decreased yield was attributed to the partial oxidation of tungsten carbide during the reaction operation.

On the other hand, similar to the $\mathrm{Ni}-\mathrm{W}_{2} \mathrm{C} / \mathrm{AC}$ catalyst we first studied, all the tungsten carbide catalysts suffered from metal leaching during the reaction. After each run, traces of tungsten $(\sim 100 \mathrm{ppm})$ were detected in the liquid solution by inductively coupled plasma (ICP) measurements, and the tungsten carbide loadings on the catalysts gradually decreased with catalyst recycling. This flaw of the tungsten carbide catalysts casted a shadow on their practical application in the CEG process. Although the tungsten carbide catalysts cannot meet all the requirements needed in practical application, they have opened a novel route for biomass conversion to value-added bulk chemicals, and provided valuable clues for further exploring for more suitable catalysts for the CEG process.

\section{2. $M(8,9,10)-W$ bimetallic catalysts}

Since the discovery of the unique catalytic behavior of tungsten carbide catalysts for cellulose conversion to EG, it was of great interest to find whether there are other catalysts with similar or better performance for EG production by the CEG process. Furthermore, it was important to understand the synergistic effect between $\mathrm{Ni}$ and $\mathrm{W}_{2} \mathrm{C}$ so that this synergy can be employed in new type of catalysts to obtain high $\mathrm{EG}$ yields.

One strategy to study the essential of the synergistic effect and to develop new catalysts was to separate the catalytic functions of tungsten carbide into two parts, i.e., employing Group 8 , 9 , or 10 metals $(M(8,9,10))$ to replace the hydrogenation function of the tungsten carbide, but retaining the hydrogenation-inert metallic tungsten in the catalyst. Accordingly, the tungstenic bimetallic catalysts we designed comprise two active components, i.e. $\mathrm{M}(8,9,10)$ metals for the hydrogenation and metallic tungsten for the degradation [56,92]. The two active components were co-loaded on the same support, or physically mixed for the reaction.

The catalytic results proved that our strategy was valid. On the Ru-W/AC, Pd-W/AC, Pt-W/AC, Ir-W/AC, and Ni-W/SBA-15 catalysts, the EG yields reach a high range of $50 \%-76 \%$, which 
was similar to the performance of tungsten carbide catalysts. The best performance was obtained on a series of $\mathrm{Ni}-\mathrm{W} /$ SBA-15 catalysts, over which the maximum EG yield reached $76.1 \%$. Moreover, the distribution of polyol products (EG, PG, erythritol, and hexitols) can be tuned by varying the ratios of $\mathrm{Ni}$ to $\mathrm{W}$ (Fig. 1). In addition, the physically mixed catalysts of $\mathrm{W} / \mathrm{AC}$ and Ni/AC also gave a good EG yield of $46.6 \%$, strongly suggesting that the CEG process involved several cascade reactions that independently occurred on different functional sites of the catalysts. Experimental evidence showed that the tungsten species played determining roles in the selective degradation of sugars into $\mathrm{C}_{2}$ and other unsaturated molecules, whereas the $M(8,9,10)$ metals carried out the hydrogenating of the unsaturated compounds to EG and polyols. A good balance between $\mathrm{C}-\mathrm{C}$ cracking and hydrogenation determined the final product distribution. Efficient catalysts for the catalytic conversion of cellulose to a desired polyol can be designed by following balance.

To probe the upper limit of feedstock concentration and its influence in the CEG process, we investigated cellulose conversion at an ultra-high concentration of $28 \%$ (weight ratio of cellulose to water and catalyst $=28: 100: 1.7)$. After the reaction, the thick slurry of microcrystalline cellulose feedstock was completely degraded with an EG yield of $65.0 \%$ over the $5 \% \mathrm{Ni}-25 \% \mathrm{~W} / \mathrm{SBA}-15$ catalyst. These results clearly demonstrated that the tungstenic bimetallic catalysts are highly effective and selective for the CEG process.

As for catalyst stability, unfortunately, we and other groups found that the tungstenic bimetallic catalysts were also not hydrothermally stable, which was caused by metal leaching and support dissolving in the hot water [24,93]. A challenge still exists to develop robust catalysts for the CEG process for the commercial application.

\subsection{Tungsten acid based composite catalysts}

As mentioned above, the studies on the tungsten carbide and tungstenic bimetallic catalysts showed that the tungsten species in a low valence state $(0$ to +2$)$ are effective in forming $\mathrm{C}_{2}$ molecules with high selectivity in the CEG process. For in-

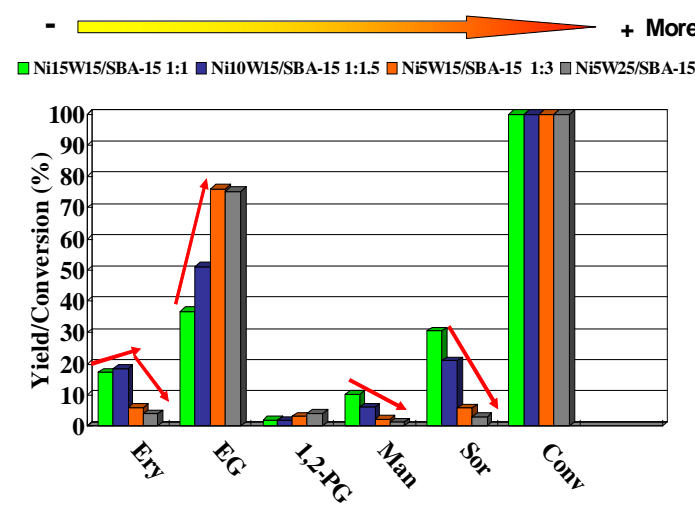

Fig. 1. Product distribution tuning as a function of $\mathrm{Ni} / \mathrm{W}$ mass ratio in the Ni-W/SBA-15 bimetallic catalyst [56]. Conv, Ery, EG, 1,2-PG, Mann, and Sor represent cellulose conversion and yields of erythritol, ethylene glycol, 1,2-propylene glycol, mannitol, and sorbitol, respectively. stance, Zhao et al. [57] studied tungsten phosphide catalysts for cellulose conversion and found that the tungsten phosphide also behaved similarly to the tungsten carbide catalysts, particularly when the WP was promoted with a small amount of nickel. Thus, these results triggered a new question of whether all the tungsten compounds are generally effective for the CEG, including those tungsten species in the fully oxidized state. In other words, what is the active site for the selective degradation of cellulose?

For a solid catalyst, the heterogeneous catalytic reaction takes place on its surface. Actually, even on the surfaces of tungsten carbide and metallic tungsten catalysts, there exist layers of tungsten oxide, which are formed in an oxidation atmosphere or during the hydrothermal reaction [94-96]. Therefore, it cannot be excluded that the tungsten oxide layers on the tungsten carbide or metallic tungenic catalysts also play some important roles in the CEG process. To confirm this conjecture, we designed a composite catalyst of $\mathrm{Ru} / \mathrm{AC}$ and tungsten acid for the CEG process [59]. By optimizing the catalyst composition to match the functions of $\mathrm{Ru} / \mathrm{AC}$ and tungsten acid, more than $50 \%$ EG yield was obtained. When a variety of tungsten compounds, e.g. phosphotungstic acid, tungsten trioxide, ammonium metatungstate, and silicotungstic acid were combined with noble metal or nickel catalysts and employed in the CEG, EG yields in a range of $32 \%-53 \%$ were obtained. Thus, it was clearly demonstrated that the tungsten species in a high valence state $(\geq+2)$ were effective for the CEG process. Thus, the range of available tungstenic catalysts for the EG production was vastly broadened [97].

Among a variety of tungsten compounds, tungsten acid shows a unique phase transfer behavior during the reaction, which is controlled by the reaction temperature and reaction atmosphere. It dissolves in hot water and a hydrogen atmosphere to form soluble tungsten bronze $\left(\mathrm{H}_{x} \mathrm{WO}_{3}\right)$ during the reaction $[98,99]$, and then turns to solid tungsten acid precipitates at ambient temperature upon exposure to air after reaction. This endows it both the high efficiency of homogeneous catalysts and the readily recycled advantage of heterogeneous catalysts. In one instance, the Ru/AC-tungsten acid catalyst was reused 34 times with the EG yield leveling off at ca. 50\%. The recovery percentage of solid tungsten acid was nearly $99 \%$ in each run. The most attractive composite catalyst was the Raney Ni-tungsten acid, which further improved the EG yield up to $65.4 \%, 10 \%$ higher than that of $\mathrm{Ru} / \mathrm{AC}$-tungsten acid [59,63]. It can be reused for at least 17 times without loss in the EG yield. In contrast to the tungsten carbide or metallic tungsten catalysts that were prepared by complex and harsh preparation procedures, tungsten acid is commercially available and cheap. Meanwhile, commercial Raney Ni catalyst is not only cheap but also can be conveniently recycled by magnetism separation after reaction. Due to all of these desirable properties, the Raney Ni-tungsten acid affords the best potential for use in large scale CEG process application.

Liu's group [62] independently studied tungsten trioxide in combination with a $\mathrm{Ru} / \mathrm{C}$ catalyst for cellulose conversion. They found that the functions of tungsten trioxide in the reaction were related to the domain sizes of $\mathrm{WO}_{3}$ supported on a carrier. 
When $\mathrm{WO}_{3}$ was highly dispersed below a monolayer on the supports of $\mathrm{ZrO}_{2}$ and $\mathrm{TiO}_{2}$, it just played a role of solid acid in cellulose hydrolysis to form glucose. When $\mathrm{WO}_{3}$ is in crystalline form at high loadings, it not only acts as a solid acid but also is catalytically active for $\mathrm{C}-\mathrm{C}$ bond breakage in the sugar intermediates. However, these results should be confirmed by providing more in situ evidence on the valence state of tungsten. The highest EG yield over the $\mathrm{WO}_{3}-\mathrm{Ru} / \mathrm{C}$ was $48.9 \%$, which was consistent with our results. In addition, introducing $\mathrm{AC}$ into the composite catalyst of $50 \% \mathrm{WO}_{3} / \mathrm{Al}_{2} \mathrm{O}_{3}-\mathrm{Ru} / \mathrm{C}$ dramatically changed the major product from EG to 1,2-propylene glycol. The reason was attributed to the isomerization of glucose to fructose due to catalysis by the surface basicity on the AC. In this way, the products distribution can be tuned.

In summary, tungsten acid-based catalysts have the advantages of high EG yield, outstanding reusability, and low cost. Meanwhile, the temperature-controlled phase transfer behavior of tungsten acid allows high efficiency in cellulose degradation by homogenous catalysis and easy recycling of the solid catalyst after reaction. All these superior properties suggested that tungsten acid-based catalysts are the most promising candidates for the future commercialization of the CEG process.

\subsection{Other metal based catalysts}

Besides tungstenic catalysts, some other metal oxides in combination with hydrogenation catalysts have also been developed that have reasonable activity for cellulose conversion to EG. However, these catalysts are generally less selective or effective compared to the tungstenic catalysts for EG production.

Deng et al. [68] studied the one-pot degradation of cellulose at $225^{\circ} \mathrm{C}$ in the presence of a $\mathrm{Ru} / \mathrm{C}$ catalyst and bases including $\mathrm{Ca}(\mathrm{OH})_{2}$ and a phosphate buffer. They obtained EG and 1,2-PG glycol with selectivities of $15 \%$ and $14 \%$, respectively, at $38 \%$ cellulose conversion in a phosphate buffer solution $(\mathrm{pH}=8)$. Also, they studied tin oxide modified $\mathrm{Pt} / \mathrm{Al}_{2} \mathrm{O}_{3}$ catalysts for cellulose conversion to polyols and obtained 22\% EG selectivity [69].

In another work, cellulose was pretreated with sodium hydroxide solution under different concentrations to decrease the crystallinity of the cellulose by the swelling effect. As a result, the cellulose conversion reached $59.2 \%$ with $18.1 \%$ 1,2-PG yield and $6.2 \%$ EG yield under the catalysis of $5 \% \mathrm{Ru} / \mathrm{C}$ and a trace of alkali contained in the pretreated feedstock [71]. Wang et al. [70] found that when employing carbon nanotube as a support for the $\mathrm{Ru}$ catalyst, cellulose hydrolysis was promoted and EG selectivity reached $21.5 \%$.

$\mathrm{Ni} / Z n O$ catalysts were recently explored by Wang et al. [72] for cellulose conversion. Compared with nickel catalysts supported on $\mathrm{Al}_{2} \mathrm{O}_{3}, \mathrm{TiO}_{2}, \mathrm{SiO}_{2}, \mathrm{ZrO}_{2}, \mathrm{MgO}$, activated carbon, and kieselguhr, the $\mathrm{Ni} / \mathrm{ZnO}$ catalysts showed notably higher glycol yields. Over a $20 \% \mathrm{Ni} / \mathrm{ZnO}$ catalyst, the glycol yields of 1,2-PG, EG, and 1,2-butanediol reached $70.4 \%$ after $2 \mathrm{~h}$ reaction at 245 ${ }^{\circ} \mathrm{C}$. However, different from the tungstenic catalysts we studied, the $\mathrm{Ni} / \mathrm{ZnO}$ catalysts gave more $1,2-\mathrm{PG}$ ( $34.4 \%$ yield) than EG (19.1\% yield). The high selectivity to $1,2-\mathrm{PG}$ was attributed to the basic property of the amphoteric $\mathrm{ZnO}$ support. The $\mathrm{Ni} / \mathrm{ZnO}$ showed reasonable stability, with polyol yield decreasing from $70 \%$ to $45.6 \%$ in three repeated runs. The leaching of nickel and $\mathrm{ZnO}$ as well as the poisoning by organic fragments in the products were the main reasons for the deactivation of the $\mathrm{Ni} / \mathrm{ZnO}$ catalysts.

More recently, Liang et al. [73] disclosed efficient $\mathrm{CuCr}$ catalysts for cellulose conversion to 1,2-PG and EG. Targeting practical application, the feedstock concentration was improved form $1 \mathrm{wt} \%$ to higher. After reaction at $245^{\circ} \mathrm{C}$ and $6 \mathrm{MPa} \mathrm{H}_{2}$ for $5 \mathrm{~h}, 1,2-\mathrm{PG}$ and EG yields of $36.3 \%$ and $7.6 \%$ were obtained at $10 \mathrm{wt} \%$ concentration of cellulose (weight of cellulose/weight of water $\times 100 \%$ ). With the addition of a basic $\mathrm{Ca}(\mathrm{OH})_{2}$ catalyst into the reaction, 1,2-PG and EG yields were increased to $42.6 \%$ and $31.6 \%$, respectively. The overall glycol yield in this work was very close to that of the tungstenic catalysts in the CEG process. The promoted retro-aldol condensation of hexitols due to catalysis by the base catalyst may be the main reason for the high glycol yields. The $\mathrm{CuCr}$ catalyst showed reasonable stability, giving a slightly decreased glycol yield after three runs. The aggregation of copper particles and coverage by carbon species on the copper sites were the main reasons for catalyst deactivation.

In summary, besides the tungstenic catalysts, the $\mathrm{Cu}-\mathrm{Cr}-\mathrm{Ca}$ catalysts are the most efficient catalysts for cellulose conversion to EG and 1,2-PG. However, the toxicity of $\mathrm{Cr}_{2} \mathrm{O}_{3}$ to environment must be seriously considered prior to any large scale application for the production of glycols.

\section{Reaction mechanism}

Among a variety of catalysts for the CEG process, the tungstenic catalysts showed the most distinguished performance in term of high EG selectivity and high efficiency. Based on our study of the CEG process, we propose the reaction mechanism over the tungstenic catalysts as shown in Scheme $2[24,56,59]$.

In the process of cellulose conversion to EG, the cellulose first undergoes hydrolysis to form oligosaccharides and glucose due to catalysis by the protonic acid formed in near-critical water [35]. The derived oligosaccharides and sugars are further catalytically degraded to glycol aldehyde by retro-aldol condensation in the presence of tungsten species. Although we cannot precisely describe how the tungsten species interact with oligosaccharides and sugar molecules yet, it can be concluded that the catalytic breakage of the $\mathrm{C}-\mathrm{C}$ bond selectively takes place at the position between the $\alpha-\beta$ carbons. In the degradation of glucose-based oligosaccharides, glycol aldehyde is produced because the sugars have a terminal aldehyde group. In contrast, when glucose isomerizes into fructose, $\mathrm{C}_{3}$ molecules will be formed, leading to the 1,2-PG and glycerol formation after a series of subsequent reactions, which was demonstrated in the catalytic conversion of Jerusalem Artichokes tube [61].

Another function of the tungstenic catalysts is to promote cellulose hydrolysis, particularly with tungsten acid, tungsten oxide, phosphotungstic acid, and other tungstenic catalysts with an acidic property or acidic surface (such as tungsten car- 


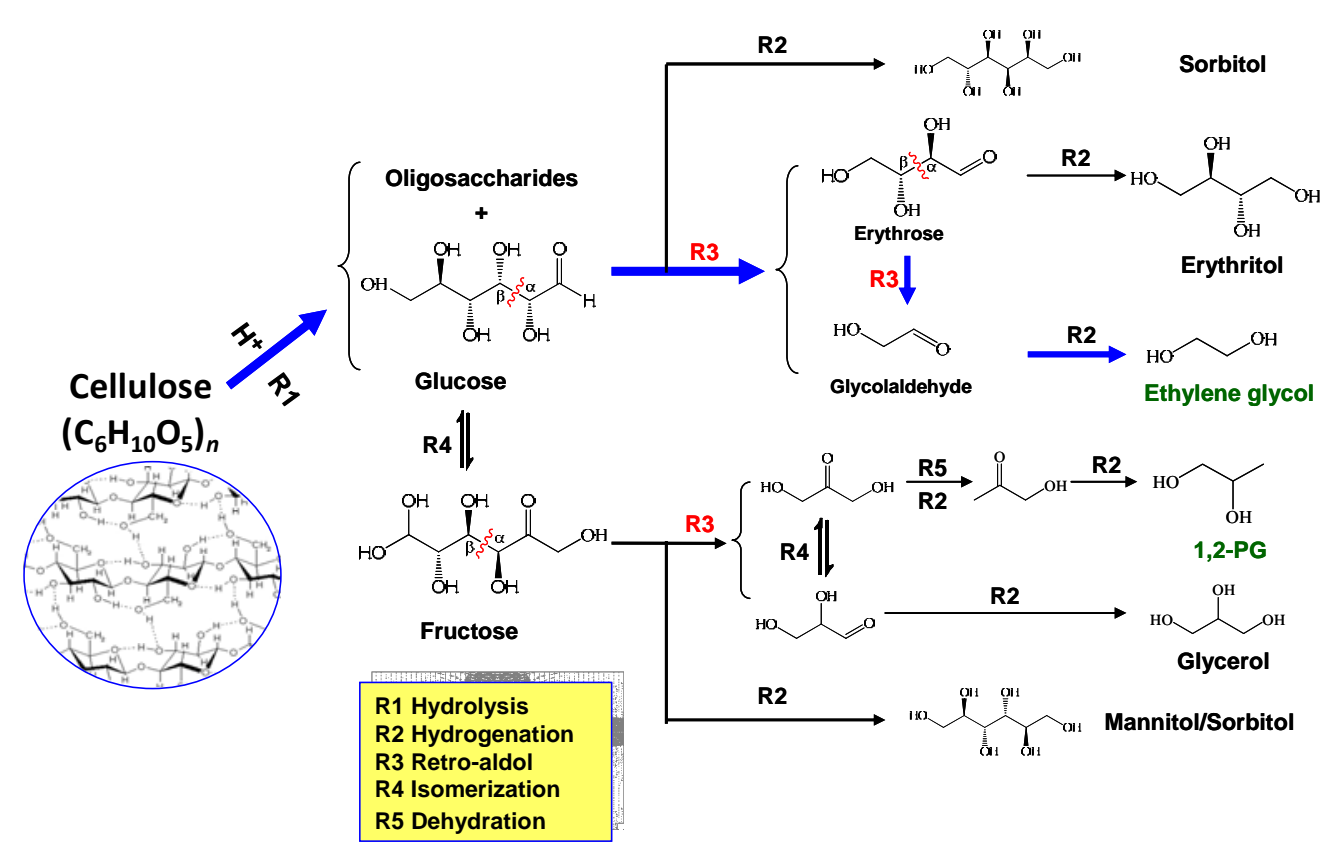

Scheme 2. Reaction mechanism of cellulose conversion to ethylene glycol over tungstenic catalysts.

bides and tungsten phosphides). Reaction kinetics study showed that the cellulose hydrolysis is the rate determining step in the CEG process. Therefore, the suitable acidity of tungstenic catalysts should benefit the reaction.

In addition, there are sufficient evidence demonstrating that the tungsten species dissolved in the solution are the species active for cellulose degradation. That is, homogeneous catalysis is involved in the cellulose conversion.

Concerning the function of the hydrogenation catalysts, they are responsible for transforming the unsaturated $\mathrm{C}_{2}$ and $\mathrm{C}_{3}$ intermediates to EG and 1,2-PG. Because the tungsten carbide and tungsten phosphide catalysts together possess the functions of cracking and hydrogenation, they are capable of producing EG without the participation of other hydrogenation metals. This is the major difference between the tungsten carbide/phosphide and noble metal catalysts for the cellulose conversion. On the other hand, when the tungsten carbide is gradually oxidized into tungsten oxide during the reaction, the hydrogenation activity is decreased, leading to EG yield loss in the catalyst recycling.

According to the reaction mechanism, the product distribution can be adjusted from EG to 1,2-PG or hexitols by tuning the balance among the reactions of hydrolysis, isomerization, retro-aldol condensation and hydrogenation. Meanwhile, an efficient catalyst and reaction process can be designed by combining homogeneous catalysis and heterogeneous catalysis.

\section{Lignocellulosic feedstock conversion}

In nature, cellulose always coexists with hemicelluose, lignin, and many other minor organic or mineral compounds such as pectin, proteins, surface wax, and inorganic ashes in plant cells [100-102]. In the bio-refinery industry of enzymatic fermentation of cellulose, it has been found that hemicellulose and lignin components have inhibition effects on enzyme activity, so the pretreatment of lignocellulosic biomass are necessary in the bio-refinery industry [103-106]. Similar requirements also exist in the paper pulp industry, where a series of pretreatment procedures are employed to separate cellulose from the raw biomass. In the initial studies of the CEG process, microcrystalline cellulose with high purity was employed to study the essential catalytic performance of a variety of catalysts. However, for the purpose of the practical application of the CEG process, the influence of the other components in biomass on cellulose conversion to EG needs to be known so that most suitable and efficient pretreatment methods can be developed accordingly.

Pang et al. [58] studied corn stalk conversion over $\mathrm{Ni}-\mathrm{W}_{2} \mathrm{C} / \mathrm{AC}$ catalysts in the CEG process. It was found that the raw corn stalk had very poor performance in the reaction, giving $18.3 \%$ EG yield and $96.1 \%$ feedstock conversion. To study the effects of the major components in the corn stalk, nine pretreatment methods were employed on the corn stalk to obtain cellulosic feedstock with different compositions of cellulose, hemicellulose, and lignin. The conversion results of pretreated samples in the CEG process showed that the EG yields have a negative correlation with the lignin content in the feedstock (Fig. 2). The aromatic products derived from lignin degradation under hydrolytic hydrogenation condition were deemed to have poisoned the hydrogenating sites of the catalysts and this accounted for the decrease of EG yield. In contrast, the hemicellose in the feedstock did not have a detrimental effect on EG yield. It was readily degraded into EG and 1,2-PG products. In addition, the swelling effect of the basic solution pretreatment on cellulose facilitated cellulose degradation. By using a basic solution of ammonia or $\mathrm{NaOH}$, or in combination with the oxidation reagent of $\mathrm{H}_{2} \mathrm{O}_{2}$ to remove lignin, the overall yields of EG and 1,2-PG reached $48 \%$ in the CEG process.

Compared with herbal biomass, woody biomass has differ- 


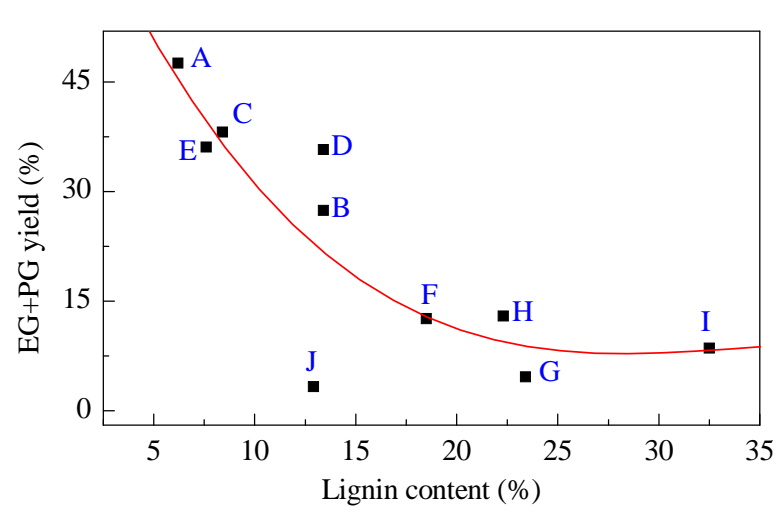

Fig. 2. Yield of EG and 1,2-PG as a function of lignin content in the corn stalk [58]. A-I represent different pretreatment methods.

ent compositions and physicochemical properties, such as less water soluble compounds, less minerals, and a relative lower content of lignin. We tested the conversion of birchwood as a typical woody biomass in the CEG process [60]. Very interestingly, not only was the cellulose transformed into EG at a high yield of $75.6 \%$ (based on sugars), but also a large portion of lignin was concurrently degraded into monophenolic compounds with yields up to $46.5 \%$ (based on lignin) over $\mathrm{Ni}-\mathrm{W}_{2} \mathrm{C} / \mathrm{AC}$ catalysts. This result suggested that the tungstenic catalysts not only convert cellulose into EG but also possess the activity to degrade lignin into fuel chemicals in the one-pot CEG process.

For the practical application of the CEG process, the EG product obtained with high concentration is of great importance to decrease the energy consumption for EG separation. Very recently, we studied the conversion of concentrated miscanthus (1-10 wt\%) with Raney Ni-tungsten acid catalysts in the CEG process [107]. Different from the corn stalk we reported previously, the raw miscanthus gave a high EG yield $(35.5 \%)$ at $1 \%$ concentration, which should be attributed to its higher cellulose content and less contaminants in the feedstock. Increasing the concentration of miscanthus led to a gradual decrease in the EG yields. The active sites of Raney Ni catalyst were found to be covered by long-chain alkanes derived from the epidermal issues of the plant and some phenolic compounds derived from lignin hydrogenolysis at high concentrations of miscanthus. After employing alkaline solution to remove the lignin and wax tissues in the miscanthus, 39.1\% EG yield and 9.2\% 1,2-PG yield were achieved in the CEG process, even with $10 \%$ miscanthus concentration. Similarly, cellulosic feedstock derived from corn cob also gave good performance of $50.6 \%$ EG yield and 7.1\% 1,2-PG yield at a high concentration of $15 \mathrm{wt} \%$.

In summary, for lignocellulosic feedstock conversion in the CEG process, pretreatment to remove the lignin, wax, and water soluble mineral compounds is beneficial for obtaining high EG yields. In contrast to enzymatic conversion of biomass in biotechnology, the hemicellulose in the feedstock does not have negative effects on EG yield, but it contributes to EG and 1,2-PG production. The concentration of feedstock can be increased to 10-15 wt\% without loss in EG yield, indicating that the CEG process can produce reasonably high concentration EG, which is very desirable for the process application.

\section{Strategy to develop the CEG process for commercialization}

For a new reaction process, whether it has good economic feasibility is the most critical issue for its future commercialization. In focusing on this central issue, the strategy to develop the CEG process should involve but not be limited to the following aspects. First, the catalysts should be cheap and have good stability to be useable with a long life so that catalyst cost is affordable. Because the tungstenic acid or oxide stayed in a chemical stable state, it can be recycled after reaction without significant loss. The stability of the hydrogenation catalyst would largely determine catalyst performance. If employing a supported hydrogenation catalyst in the reaction, active carbon would be the most suitable carrier due to its hydrothermal stability properties. Skeletal metallic catalysts such as Raney Ni and amorphous Ni alloys would be more suitable candidates as evidenced by their wide application in glucose hydrogenation, which is also operated under similar hydrothermal reaction conditions $[108,109]$. Under the restriction of maintaining the hydrogenation activity, any approach to improve the stability of hydrogenation catalysts would be favorable for the CEG process.

Another key point is that the process should have high efficiency. In lab scale experiments, the CEG process can be conducted in a batch reactor. However, for industrial application on large scales such as 100000 ton/year, the continuous reaction mode is required to ensure high efficiency in the chemical engineering operation [110]. Meanwhile, the feedstock concentration should be as high as possible to produce EG with high concentrations. This will significantly save consumption of water and energy in the whole process.

Before the reaction, the feedstock should undergo suitable pretreatment in effective and cheap ways to remove lignin from the lignocellulosic materials. This will benefit EG production and prolong catalyst lifetime. Also, a sustainable feedstock supply system should be developed within a feasible radius for biomass collection. During the reaction, conditions such as reaction temperature and pressure should be as moderate as possible to decrease cost and energy consumption. At the end of the CEG process, the EG product has to be purified to a high quality for its application in the synthesis of polyethylene teraphthalate (PET) resin [111-113]. In addition, slightly different from the EG product obtained from petroleum feedstock, the bio-EG would contain some trace of other polyol components. It is encouraging that our ongoing work on PET resin synthesis from bio-EG showed that some amounts of polyols (overall amount of 1,2-PG and 1,2-butanediol $<2 \mathrm{wt} \%$ ) contained in the bio-EG have no influence on the thermal properties (melting point, glass transition point, crystallization temperature, etc.) of the polymer. More extensive investigations should be performed to establish a sound quality standard of the bio-EG for PET resin synthesis.

Systematic work is needed to develop the CEG process into a 
commercialized industry. One shortcut for CEG application is by integrating the CEG process with some other biomass refinery industry that already exist. Then, many common procedures can be jointly shared by the bio-refinery and chemical conversion process. In this way, the largest benefits can be obtained as elucidated in the following section.

\section{Incorporating the CEG process into a bio-refinery process}

On comparing the emerging technology of biomass conversion with the well-developed petroleum refinery industry, one finds many similarities. Both feedstocks need pretreatment to meet the requirements in the followed refinery and chemical processes. There are many components or fractions contained in the raw materials, which should be separated for different uses. From the beginning feedstock to the various final products, a variety of chemical processes are involved in the whole industry chain [114]. Therefore, for the CEG process of cellulose conversion, it would be more feasible and profitable if it is integrated in the chain of some suitable biomass refinery. Here, we present a model of integrating the CEG process with the acetone- $n$-butanol-ethanol (ABE) fermentation of corn cob biomass.

Corn cob is an abundant agriculture residue, which is readily collected and obtained during grain production after harvesting and threshing the corn. It contains a relatively abundant hemicellulose component $(\sim 35 \%)$, accompanied with $\sim 40 \%$ cellulose, and $\sim 17 \%$ lignin, $\sim 5 \%$ ash, and some other water soluble components. Traditionally, corn cob is used as feedstock to produce furfural by catalysis with a strong acid. Recently, some enterprises have successfully cultivated more productive enzymes for fermenting xylose to produce acetone, $n$-butanol, and ethanol. The refinery process has been proven efficient with good $\mathrm{ABE}$ yields (weight ratio of $\mathrm{A}: \mathrm{B}: \mathrm{E}=2: 7: 1$ ) on an industrial scale (http://www.lrbgroup.cn). Compared with ethanol, butanol has many advantages including higher energy density, mixable with gasoline at any ratio, better combustion performance, and no need to modify car engines. Therefore, as a superior fuel additive, butanol is attracting more attention and should have a vast market demand in the future.

In last decade, the concept and techniques for the whole component separation and utilization of biomass have been gradually set up in the biomass refinery industry. Here, we integrate the CEG process with the $\mathrm{ABE}$ process to give a roadmap of whole biomass utilization (Scheme 3). In a typical $\mathrm{ABE}$ fermentation process, the corn cob is first ground into powder and then hydrolyzed with diluted acid to release xylose from hemicellulose for ABE production. The remaining cellulose and lignin components can be further separated into pure cellulose and lignin powders with alkali and acid treatments. The cellulosic material obtained is a kind of short fiber, which is not suitable for producing paper pulp but is an ideal feedstock for catalytic transformation to EG by the CEG process. In our lab, this kind of cellulosic biomass (containing 1\%-2\% lignin) can give $50.6 \%$ EG yield and 7.1\% 1,2-PG yield even at a high concentration of $15 \mathrm{wt} \%$. The pure lignin powder recycled can be used as a substitute for phenol chemicals in the synthesis of high value and environmentally friendly polymers. Thus, all the main components in corn cob can be utilized. Furthermore, during the fermentation for ABE production, a large amount of $\mathrm{H}_{2}$ is concurrently produced. This renewable $\mathrm{H}_{2}$ can be collected and purified for the catalytic hydrogenation in the CEG process, thus extra merit can be obtained by this integration.

In this whole map of a biomass refinery, a variety of useful energy chemicals, fuels, and natural phenolic polymer materials can be concurrently obtained for different applications. EG obtained from the CEG process can be used for PET resin synthesis. 1,2-PG can be used for the synthesis of nontoxic antifreeze or unsaturated resins. Other byproducts of polyols can be catalytically reformed to $\mathrm{H}_{2}$ or fuels as demonstrated by Dumesic et al. $[115,116]$. Butanol and ethanol obtained in the ABE process can be directly used in fuels. Acetone can be used as fine chemicals or catalytically transformed to jet fuels [117,118, http://www.militaryaerospace.com]. Lignin product can be used as a substitute for phonolic chemicals in green polymer synthesis, which emit much less hazardous gas and are more environmentally benign. Therefore, by integrating the

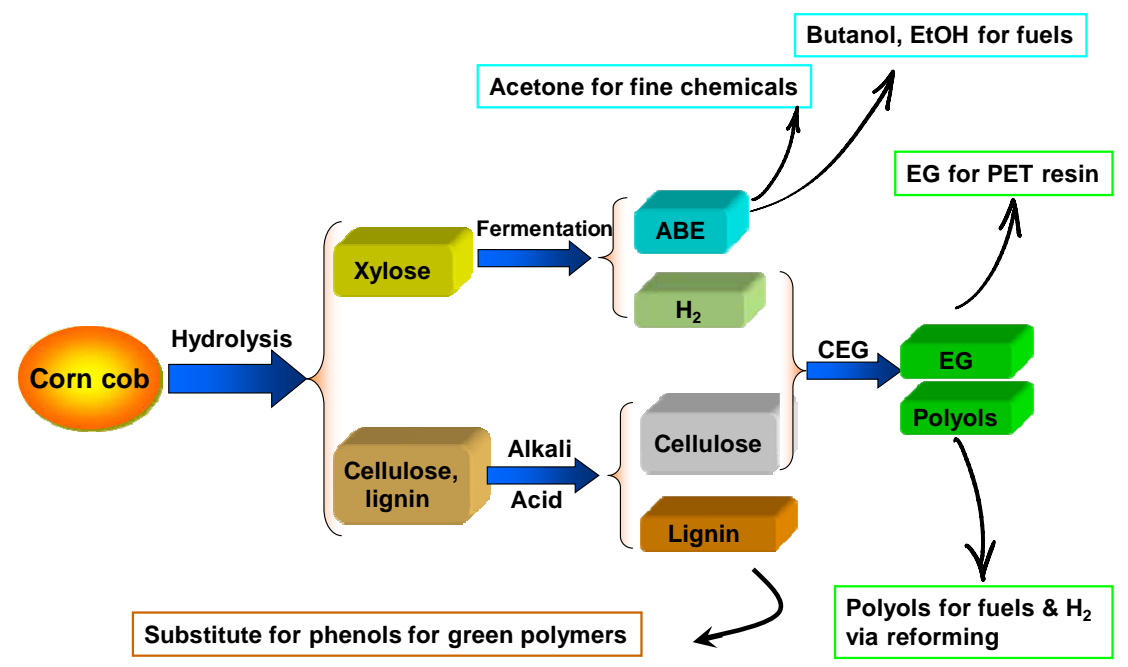

Scheme 3. Map of one-pot conversion of cellulose to EG process integrated with the acetone- $n$-butanol-ethanol bio-refinery process in the whole conversion of corn cob biomass. 
processes of biomass multi-component separation, cellulose catalytic conversion for EG production, and hemicellulose fermentation for ABE production, all the main components in the biomass are utilized to produce valuable fuels and chemicals with the largest benefit to resources and environment.

\section{Conclusions and prospects}

Since the first disclosure in 2008, the one-pot catalytic conversion of cellulose to EG has gained remarkable advances in scientific understanding and industrial application. The EG yield has been improved from $61 \%$ to $76 \%$ by more efficient tungstenic catalysts. The active components of the catalysts have been vastly broadened from tungsten carbides to binary components, which comprise tungsten and a hydrogenation metal. Catalyst stability has been significantly improved, as shown by the performance of tungsten acid-based binary catalysts. The Raney Ni-tungsten acid catalyst is the most promising candidate for CEG process industrialization due to low cost, good reusability, and easy recycling properties. In addition, some non-tungstenic catalysts, including $\mathrm{Ni} / \mathrm{ZnO}$ and $\mathrm{Cu}-\mathrm{Cr}-\mathrm{Ca}$ catalysts, have been explored and shown to give reasonably good performance, providing more options for cellulose conversion to EG and 1,2-PG.

The reaction mechanism study showed that in the presence of tungstenic catalysts, the CEG process occurs by cascade reactions involving homogenous catalysis and heterogeneous catalysis. The oligosaccharides and glucose derived from cellulose hydrolysis undergo retro-aldol condensation catalyzed by dissolved tungsten species to form glycol aldehyde, which is further hydrogenated into EG over a heterogeneous hydrogenation catalyst. By tuning the balance among the reactions of hydrolysis, retro-aldol condensation, and hydrogenation, the polyol product distribution can be adjusted.

Typical herbal and woody raw cellulosic biomass have been employed in the CEG process to show the influence of the different components in biomass on the EG production, and effective pretreatment has been developed. After removal of the lignin components, the cellulosic biomass can give 50.6\% EG yield even at high concentrations of $10-15 \mathrm{wt} \%$ in the reaction. All of these progress as well as other contributing trials have paved a good foundation for understanding the CEG process and its future practical application.

There are still some deep fundamental scientific questions that should be answered in the future. (1) How do the tungsten species interact with sugar and oligosaccharide molecules? (2) What is the kinetics of the cascade reactions involved in the process? On the other hand, from the commercialization point of view, a high efficiency reaction process, new techniques for EG separation with less energy consumption, and valuable utilization of byproducts are needed. The accumulated knowledge in this field will greatly promote CEG process industrialization. Meanwhile, rapid advances in the bio-refinery industry would also provide more collaboration opportunities to design a multi-win situation. In this way, the future world would eventually benefit from the clean and sustainable utilization of biomass.

\section{References}

[1] Bentley R W. Energy Policy, 2002, 30: 189

[2] Verbruggen A, Fischedick M, Moomaw W, Weir T, Nadai A, Nilsson L J, Nyboer J, Sathaye J. Energy Policy, 2010, 38: 850

[3] Wang Q, Chen Y. Renew Sustain Energy Rev, 2010, 14: 1989

[4] Zeng M, Li C, Zhou L S. Renew Sustain Energy Rev, 2013, 20: 36

[5] Maki-Arvela P, Salmi T, Holmbom B, Willfor S, Murzin D Y. Chem Rev, 2011, 111: 5638

[6] Petrus L, Noordermeer M A. Green Chem, 2006, 8: 861

[7] Mohan D, Pittman C U Jr, Steele P H. Energy Fuels, 2006, 20: 848

[8] Corma A, Iborra S, Velty A. Chem Rev, 2007, 107: 2411

[9] Hayes D J. Catal Today, 2009, 145: 138

[10] Fukuoka A, Dhepe P L. Chem Record, 2009, 9: 224

[11] Bozell J J. Science, 2010, 329: 522

[12] Holm M S, Saravanamurugan S, Taarning E. Science, 2010, 328: 602

[13] Zakzeski J, Bruijnincx P C A, Jongerius A L, Weckhuysen B M. Chem Rev, 2010, 110: 3552

[14] Serrano-Ruiz J C, Dumesic J A. Energy Environ Sci, 2011, 4: 83

[15] Zhou C H, Xia X, Lin C X, Tong D S, Beltramini J. Chem Soc Rev, 2011, 40: 5588

[16] Rosatella A A, Simeonov S P, Frade R F M, Afonso C A M. Green Chem, 2011, 13: 754

[17] Climent M J, Corma A, Iborra S. Green Chem, 2011, 13: 520

[18] Gallezot P. Chem Soc Rev, 2012, 41: 1538

[19] Alonso D M, Wettstein S G, Dumesic J A. Chem Soc Rev, 2012, 41: 8075

[20] Takagaki A, Nishimura S, Ebitani K. Catal Surv Asia, 2012, 16: 164

\section{Graphical Abstract}

Chin. J. Catal., 2014, 35: 602-613 doi: 10.1016/S1872-2067(14)60013-9

\section{One-pot catalytic conversion of cellulose to ethylene glycol and other chemicals: From fundamental discovery to potential commercialization \\ Mingyuan Zheng, Jifeng Pang, Aiqin Wang, Tao Zhang* Dalian Institute of Chemical Physics, Chinese Academy of Sciences}

One-pot conversion of cellulose to ethylene glycol (EG) and other chemicals has achieved significant progress, which gives a good foundation for industrializing this new process for EG production.

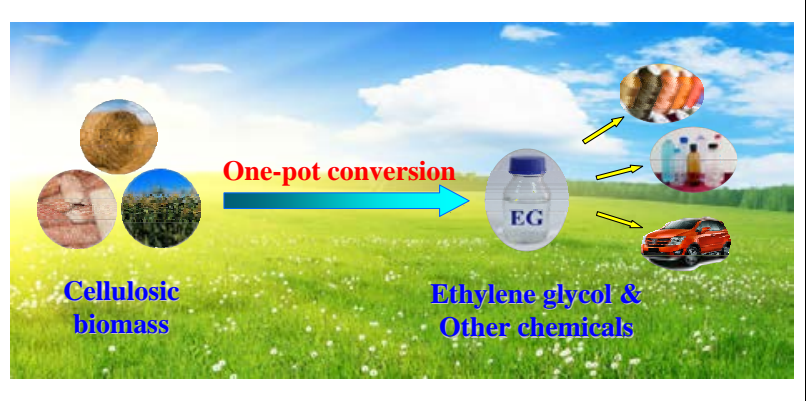


[21] Ruppert A M, Weinberg K, Palkovits R. Angew Chem Int Ed, 2012, 51: 2564

[22] Song Q, Wang F, Xu J. Chem Commun, 2012, 48: 7019

[23] Kobayashi H, Fukuoka A. Green Chem, 2013, 15: 1740

[24] Wang A Q, Zhang T. Acc Chem Res, 2013, 46: 1377

[25] Rackemann D W, Doherty W O S. Int Sugar J, 2013, 115: 28

[26] Alonso D M, Wettstein S G, Dumesic J A. Green Chem, 2013, 15: 584

[27] Ma J P, Yu W Q, Wang M, Jia X Q, Lu F, Xu J. Chin J Catal (马继平, 于 维强, 王敏, 贾秀全, 路芳, 徐杰. 催化学报), 2013, 34: 492

[28] Wang Y L, Deng W P, Wang B J, Zhang Q H, Wan X Y, Tang Z C, Wang Y, Zhu C, Cao Z X, Wang G C, Wan H L. Nat Commun, 2013, 4, doi:10.1038/ncomms3141

[29] Liu Z, Feng G, Pan C Y, Li W, Chen P, Lou H, Zheng X M. Chin J Catal (刘镇, 冯刚, 潘春燕, 李望, 陈平, 楼辉, 郑小明. 催化学报), 2012, 33: 1696

[30] Du X L, Liu Y M, Wang J Q, Cao Y, Fan K N. Chin J Catal (杜贤龙, 刘 永梅, 王建强, 曹勇, 范康年. 催化学报), 2013, 34: 993

[31] Yue H R, Zhao Y J, Ma X B, Gong J L. Chem Soc Rev, 2012, 41: 4218

[32] Chen Y D, Li G F. J Univ Sci Technol China (陈贻盾, 李国方. 中国科 学技术大学学报), 2009, 39: 1

[33] Yang Z, Ren N, Tang Y. Petrochem Technol (杨志剑, 任楠, 唐烦. 石油化工), 2010, 39: 562

[34] Fukuoka A, Dhepe P L. Angew Chem Int Ed, 2006, 45: 5161

[35] Luo C, Wang S, Liu H C. Angew Chem Int Ed, 2007, 46: 7636

[36] Deng W P, Tan X S, Fang W H, Zhang Q H, Wang Y. Catal Lett, 2009, 133: 167

[37] Palkovits R, Tajvidi K, Procelewska J, Rinaldi R, Ruppert A. Green Chem, 2010, 12: 972

[38] Geboers J, Van De Vyver S, Carpentier K, De Blochouse K, Jacobs P, Sels B. Chem Commun, 2010, 46: 3577

[39] Van De Vyver S, Geboers J, Dusselier M, Schepers H, Vosch T, Zhang L, Van Tendeloo G, Jacobs P A, Sels B F. ChemSusChem, 2010, 3: 698

[40] Ding L N, Wang A Q, Zheng M Y, Zhang T. ChemSusChem, 2010, 3: 818

[41] Kobayashi H, Ito Y, Komanoya T, Hosaka Y, Dhepe P L, Kasai K, Hara K, Fukuoka A. Green Chem, 2011, 13: 326

[42] Kobayashi H, Matsuhashi H, Komanoya T, Hara K, Fukuoka A. Chem Commun, 2011, 47: 2366

[43] Yang P F, Kobayashi H, Fukuoka A. Chin J Catal (催化学报), 2011, 32: 716

[44] Liu M, Deng W P, Zhang Q H, Wang Y L, Wang Y. Chem Commun, 2011, 47: 9717

[45] Han J W, Lee H. Catal Commun, 2012, 19: 115

[46] Pang J F, Wang A Q, Zheng M Y, Zhang Y H, Huang Y Q, Chen X W, Zhang T. Green Chem, 2012, 14: 614

[47] Shrotri A, Tanksale A, Beltramini J N, Gurav H, Chilukuri S V. Catal Sci Technol, 2012, 2: 1852

[48] Wu Z J, Ge S H, Ren C X, Zhang M H, Yip A, Xu C M. Green Chem, 2012, 14: 3336

[49] Yang P F, Kobayashi H, Hara K, Fukuoka A. ChemSusChem, 2012, 5: 920

[50] Liang G F, Cheng H Y, Li W, He L M, Yu Y C, Zhao F Y. Green Chem, 2012, 14: 2146

[51] Chen J Z, Wang S P, Huang J, Chen L M, Ma L L, Huang X. ChemSusChem, 2013, 6: 1545

[52] Ji N, Zhang T, Zheng M Y, Wang A Q, Wang H, Wang X P, Chen J G. Angew Chem Int Ed, 2008, 47: 8510

[53] Zhang T, Ji N, Zheng M Y, Wang A Q, Wang X P, Chen J. US Patent 8338326. 2012

[54] Ji N, Zhang T, Zheng M Y, Wang A Q, Wang H, Wang X D, Shu Y Y,
Stottlemyer A L, Chen J G. Catal Today, 2009, 147: 77

[55] Zhang Y H, Wang A Q Zhang T. Chem Commun, 2010, 46: 862

[56] Zheng M Y, Wang A Q, Ji N, Pang J F, Wang X D, Zhang T. ChemSusChem, 2010, 3: 63

[57] Zhao G H, Zheng M Y, Wang A Q, Zhang T. Chin J Catal (赵冠鸿, 郑 明远, 王爱琴, 张涛. 催化学报), 2010, 31: 928

[58] Pang J F, Zheng M Y, Wang A Q, Zhang T. Ind Eng Chem Res, 2011, 50: 6601

[59] Tai Z J, Zhang J Y, Wang A Q Zheng M Y, Zhang T. Chem Commun, 2012, 48: 7052

[60] Li C Z, Zheng M Y, Wang A Q Zhang T. Energy Environ Sci, 2012, 5: 6383

[61] Zhou L K, Wang A Q, Li C Z, Zheng M Y, Zhang T. ChemSusChem, 2012, 5: 932

[62] Liu Y, Luo C, Liu H C. Angew Chem Int Ed, 2012, 51: 3249

[63] Tai Z J, Zhang J Y, Wang A Q, Pang J F, Zheng M Y, Zhang T. ChemSusChem, 2013, 6: 652

[64] Ooms R, Dusselier M, Geboers J A, Op De Beeck B, Verhaeven R, Gobechiya E, Martens J, Redl A, Sels B F. Green Chem, 2014, 16: 695

[65] Zhao G H, Zheng M Y, Zhang J Y, Wang A Q, Zhang T. Ind Eng Chem Res, 2013, 52: 9566

[66] Zhou L K, Pang J F, Wang A Q, Zhang T. Chin J Catal (周立坤, 庞纪 峰, 王爱琴, 张涛. 催化学报), 2013, 34: 2041

[67] Ji N, Zheng M Y, Wang A Q, Zhang T, Chen J G. ChemSusChem, 2012, 5: 939

[68] Deng T Y, Sun J Y, Liu H C. Sci China Chem, 2010, 53: 1476

[69] Deng T Y, Liu H C. Green Chem, 2013, 15: 116

[70] Wang H J, Zhu L L, Peng S, Peng F, Yu H, Yang J. Renew Energy, 2012, 37: 192

[71] Liu M R, Wang H, Han J Y, Niu Y F. Carbohydrate Polym, 2012, 89: 607

[72] Wang X C, Meng L Q, Wu F, Jiang Y J, Wang L, Mu X D. Green Chem, 2012, 14: 758

[73] Xiao Z H, Jin S H, Pang M, Liang C H. Green Chem, 2013, 15: 891

[74] Xu Y P, Tian Z J, Lin L W. Chin J Catal (徐云鹏, 田志坚, 林励吾. 催 化学报), 2004, 25: 331

[75] Levy R B, Boudart M. Science, 1973, 181: 547

[76] Zaanen J, Sawatzky G A, Allen J W. Phys Rev Lett, 1985, 55: 418

[77] Jansen S A, Hoffmann R. Surf Sci, 1988, 197: 474

[78] Chen J G. Chem Rev, 1996, 96: 1477

[79] Chen X W, Zhang T, Xia L G, Li T, Zheng M Y, Wu Z L, Wang X D, Wei Z B, Xin Q, Li C. Catal Lett, 2002, 79: 21

[80] Chen X W, Zhang T, Ying P L, Zheng M Y, Wu W C, Xia L G, Li T, Wang X D, Li C. Chem Commun, 2002: 288

[81] Chen X W, Zhang T, Zheng M Y, Wu Z L, Wu W C, Li C. J Catal, 2004, 224: 473

[82] Chen X W, Zhang T, Zheng M Y, Xia L G, Li T, Wu W C, Wang X D, Li C. Ind Eng Chem Res, 2004, 43: 6040

[83] Zheng M Y, Cheng R H, Chen X W, Li N, Cong Y, Wang X D, Zhang T. Chem J Chin Univ (郑明远, 程瑞华, 陈小伟, 李宁, 从昱, 王晓东, 张涛. 高等学校化学学报), 2005, 26: 623

[84] Zheng M Y, Chen X W, Cheng R H, Li N, Sun J, Wang X D, Zhang T. Catal Commun, 2006, 7: 187

[85] Cheng R H, Shu Y Y, Zheng M Y, Li L, Sun J, Wang X D, Zhang T. J Catal, 2007, 249: 397

[86] Sun J, Wang X T, Wang X D, Zheng M Y, Wang A Q, Zhang T. Chin J Catal (孙军, 王兴堂, 王晓东, 郑明远, 王爱琴, 张涛. 催化学报), 2008, 29: 710

[87] Sun J, Zheng M Y, Wang X D, Wang A Q, Cheng R H, Li T, Zhang T. Catal Lett, 2008, 123: 150

[88] Liang C H, Ding L, Wang A Q, Ma Z Q, Qiu J S, Zhang T. Ind Eng 
Chem Res, 2009, 48: 3244

[89] Ding L N, Shu Y Y, Wang A Q, Zheng M Y, Li L, Wang X D, Zhang T. Appl Catal A, 2010, 385: 232

[90] Pang J F, Wang A Q Zheng M Y, Zhang T. Chem Commun, 2010, 46: 6935

[91] Kobayashi H, Komanoya T, Hara K, Fukuoka A. ChemSusChem, 2010, 3: 440

[92] Zhang T, Zheng M Y, Ji N, Wang A Q, Shu Y Y, Wang H, Wang X D, Chen J G. WO Patent 2010045766-A1; CN Patent 101723802-A; US Patent 2010256424-A1; MX Patent 2010011284-A1; CA Patent 2725248-A1; US Patent 7960594-B2; EP Patent 2338867-A1; MX Patent 305208-B. 2010

[93] Baek I G, You S J, Park E D. Bioresour Technol, 2012, 114: 684

[94] Iglesia E, Ribeiro F H, Boudart M, Baumgartner J E. Catal Today, 1992, 15: 307

[95] Katrib A, Hemming F, Wehrer P, Hilaire L, Maire G. Top Catal, 1994, 1: 75

[96] Alvarez-Merino M A, Carrasco-Marin F, Fierro J L G, MorenoCastilla C.J Catal, 2000, 192: 363

[97] Zhang T, Tai Z J, Wang A Q, Zheng M Y. US Patent 13/395470. 2012

[98] Dickens P G, Whittingham M S. Q Rev Chem Soc, 1968, 22: 30

[99] Ingham B, Hendy S C, Chong S V, Tallon J L. Phys Rev B, 2005, 72: 075109

[100] Himmel M E, Ding S Y, Johnson D K, Adney W S, Nimlos M R, Brady J W, Foust T D. Science, 2007, 315: 804

[101] Zhao X B, Zhang L H, Liu D H. Biofuels Bioprod Bioref, 2012, 6: 465

[102] DeMartini J D, Pattathil S, Miller J S, Li H, Hahn M G, Wyman C E. Energy Environ Sci, 2013, 6: 898
[103] Li K, Jin Y L, Gan M Z, Liu X F, Zhao H. Chin J Appl Environ Biol, 2008, 14: 877

[104] Hendriks A T W M, Zeeman G. Bioresour Technol, 2009, 100: 10

[105] Jaeger G, Buechs J. Biotechnol J, 2012, 7: 1122

[106] Sathitsuksanoh N, George A, Zhang Y H P. J Chem Technol Biotechnol, 2013, 88: 169

[107] Pang J F, Zheng M Y, Wang A Q, Sun R Y, Wang H, Jiang Y, Zhang T. AIChE J, DOI: 10.1002/aic.14406

[108] Xie W H, Zong B N. Prog Chem (谢文华, 宗保宁. 化学进展), 2009, 21: 2474

[109] Zong B N, Mu X H, Zhang X X, Meng X S, Qiao M H. Chin J Catal (宗保宁, 慕旭宏, 张晓昕, 孟祥斿, 乔明华. 催化学报), 2013, 34: 828

[110] Zhang T, Wang A Q Zheng M M, Li C, Pang J, Kalnes T N, Chen J Q, Kocal J A. US Patent 08323937. 2012

[111] Yamagishi M. JP Patent 2004307366-A; JP Patent 4356342-B2. 2004

[112] Kalagias P. WO Patent 2008057317-A1. 2008

[113] Pang J F, Zheng M Y, Jiang Y, Wang A Q, Zhang T. Chem Ind Eng Prog (庞纪峰, 郑明远, 姜宇, 王爱琴, 张涛. 化工进展), 2013, 32: 2006

[114] Sadhukhan J, Ng K S. Ind Eng Chem Res, 2011, 50: 6794

[115] Huber G W, Shabaker J W, Dumesic J A. Science, 2003, 300: 2075

[116] Chheda J N, Huber G W, Dumesic J A. Angew Chem Int Ed, 2007, 46: 7164

[117] Anbarasan P, Baer Z C, Sreekumar S, Gross E, Binder J B, Blanch H W, Clark D S, Toste F D. Nature, 2012, 491: 235

[118] Li G Y, Li N, Yang J F, Wang A Q, Wang X D, Cong Y, Zhang T. Bioresour Technol, 2013, 134: 66

\title{
纤维素直接催化转化制乙二醇及其他化学品：从基础研究发现到潜在工业应用
}

\author{
郑明远, 庞纪峰, 王爱琴, 张 涛* \\ 中国科学院大连化学物理研究所催化基础国家重点实验室, 辽宁大连 116023
}

摘要: 纤维素直接催化转化制乙二醇是一条极具吸引力的生物质转化途径, 有助于减轻化石能源资源的消耗。综述了从该反应 途径的发现到获得高效、高稳定性催化剂的快速发展过程。基于对铇基催化剂的大量研究结果, 本文讨论了反应机制, 明确了 反应路径、催化剂状态、铇物种及加氢催化活性中心各自在串联反应中的作用。围绕该反应过程的工业化应用需要, 讨论了有 关原生木质纤维素生物质催化转化以及高效反应过程的发展策略。在此基础上, 将纤维素催化转化制乙二醇过程与生物质发酵 制丙酮-丁醇-乙醇的生物炼制路线进行整合, 构建出一个理想的反应过程潜在应用范例。最后, 对纤维素催化转化制乙二醇反 应过程进行了总结和前景展望.

关键词: 生物质; 纤维素; 乙二醇; 铇基催化剂; 加氢

收稿日期: 2013-11-21. 接受日期: 2013-12-30. 出版日期: 2014-05-20.

*通讯联系人. 电话: (0411)84379015; 传真: (0411)84691570; 电子信箱: taozhang@dicp.ac.cn

基金来源：国家重点基础研究发展计划(973计划, 2009CB226102); 国家自然科学基金(21376239, 21306191, 21176235).

本文的英文电子版由Elsevier出版社在ScienceDirect上出版(http://www.sciencedirect.com/science/journal/18722067). 